\title{
A COMPARISON OF VENTURI AND SIDE-ARM VENTILATION IN ANAESTHESIA FOR BRONCHOSCOPY
}

\author{
Edward Carden, M.A., M.B., B.CHIR., F.R.C.P.(C), Walter W. Burns, M.D., \\ Noel B. McDevitT, m.D., and Ted Carson, M.D."
}

\begin{abstract}
EvER SINCE 1967, when Sanders published a paper ${ }^{1}$ showing the Venturi principle for ventilating patients undergoing bronchoscopy, this technique has become increasingly popular. Many papers ${ }^{2-5}$ have been published promoting the use of the Venturi principle which in most cases entails a 16-gauge needle aimed distally down the proximal end of a bronchoscope through which a jet of oxygen is intermittently injected to produce positive pressure ventilation in the lungs (Figure 1). In 1970, a paper was published ${ }^{6}$ which described the use of the sidearm of the older type of Chevalier Jackson bronchoscope as a means of getting oxygen into the bronchoscope. This system was claimed to deliver higher pressures to the patient's lungs, resulting in lower $\mathrm{CO}_{2}$ levels; and it was also claimed that it would deliver 100 per cent oxygen to the distal end of the bronchoscope (Figure 2 ). There has been certain skepticism in the minds of many people that this technique is superior to the use of a Venturi principle. We differentiate the two because it is claimed that the second technique described does not utilize a Venturi principle and that there is no air entrainment.

Because of this controversy a short clinical trial was undertaken to determine the relative merits of these two techniques.
\end{abstract}

\section{METHOD}

Sixteen adult patients presenting for bronchoscopy were ventilated with either the Sidearm system or the Venturi system on a random basis. For the Venturi system, the patients were bronchoscoped with a Chevalier Jackson-Hollinger type bronchoscope fitted with a Venturi oxygen injector, to which oxygen was supplied through a flow interrupter (Blowgun) from an adjustable pressure reducing valve connected to pipeline oxygen at $50 \mathrm{psi}$ (this system is marketed by the Pilling Corporation) (Figure 3 ). The pressure reducing valve was adjusted to give the highest possible pressure ( $50 \mathrm{psi}$ ), which is the accepted technique with this system. For the Sidearm system of ventilation, old type Chevalier Jackson tapered bronchoscopes with small sidearms were used. Oxygen was supplied from the pipeline through an adjustable pressure reducing valve and a system for intermittent oxygen flow as described in the original paper ${ }^{6}$ (Figure 4). The pressure reducing valve was adjusted to give a pressure at the tip of the bronchoscope of

\footnotetext{
"From the Department of Anesthesiology and the Department of Surgery, University of North Carolina School of Medicine and North Carolina Memorial Hospital, Chapel Hill, North Carolina 27514, U.S.A.
} 


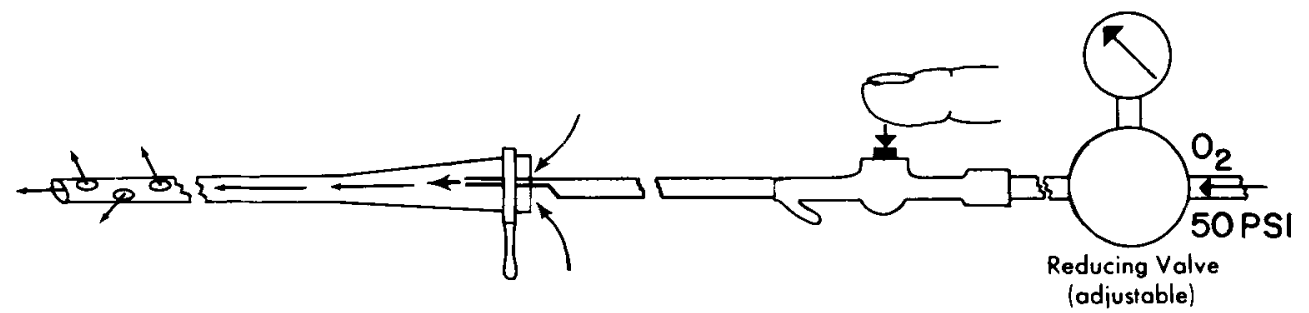

Figure 1. Showing schematically the Venturi system for ventilation through a bronchoscope.

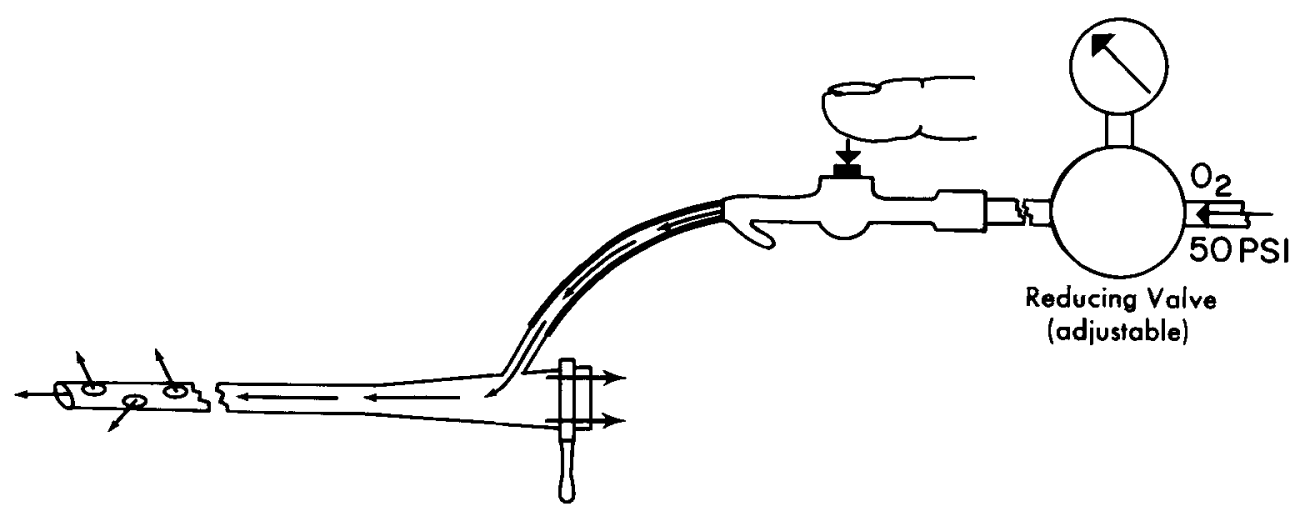

Figure 2. Showing schematically the Sidearm system for ventilation through a bronchoscope.

$45 \mathrm{~cm} \mathrm{H}_{2} \mathrm{O}$ with all side holes closed, to conform to the accepted practice with this technique.

Age of the patients varied from 35 years to 75 years and they were bronchoscoped because some pulmonary disease was suspected. Premedication was diazepam $10 \mathrm{mg}$ intramuscularly and, just prior to anaesthesia, $0.6 \mathrm{mg}$ of Atropine intravenously. Following four minutes of pre-oxygenation, anaesthesia was induced with methohexital (Brevital ${ }^{\circledR}$ ) intravenously in a sleep dose. The patients were then paralyzed with succinylcholine and the trachea and cords were sprayed with 4 per cent lidocaine. The bronchoscope was then passed, connected to the ventilating system and the patients were ventilated by an intermittent jet of oxygen into the bronchoscope. The patients were kept asleep with intermittent intravenous doses of methohexital and were kept paralyzed by succinylcholine in an intravenous drip consisting of one gram of succinylcholine in a $500 \mathrm{cc}$ bottle of 5 per cent dextrose in 0.2 sodium chloride. During the anaesthetic the blood pressure, EKG (via telemetry), ${ }^{7}$ and pulse rate were constantly monitored. Our aim was to keep the arterial $\mathrm{CO}_{2}$ level between 30 and 40 torr. Arterial blood samples were taken from the radial artery prior to pre-oxygenation and ten minutes after induction of anaesthesia and immediately analyzed on an IL Model 113 blood gas analyzer. Because much lower pressures are available from the Venturi system 8 the method of ventilation differed in the two techniques. With the sidearm technique inspiration was long and deep, with an even longer 


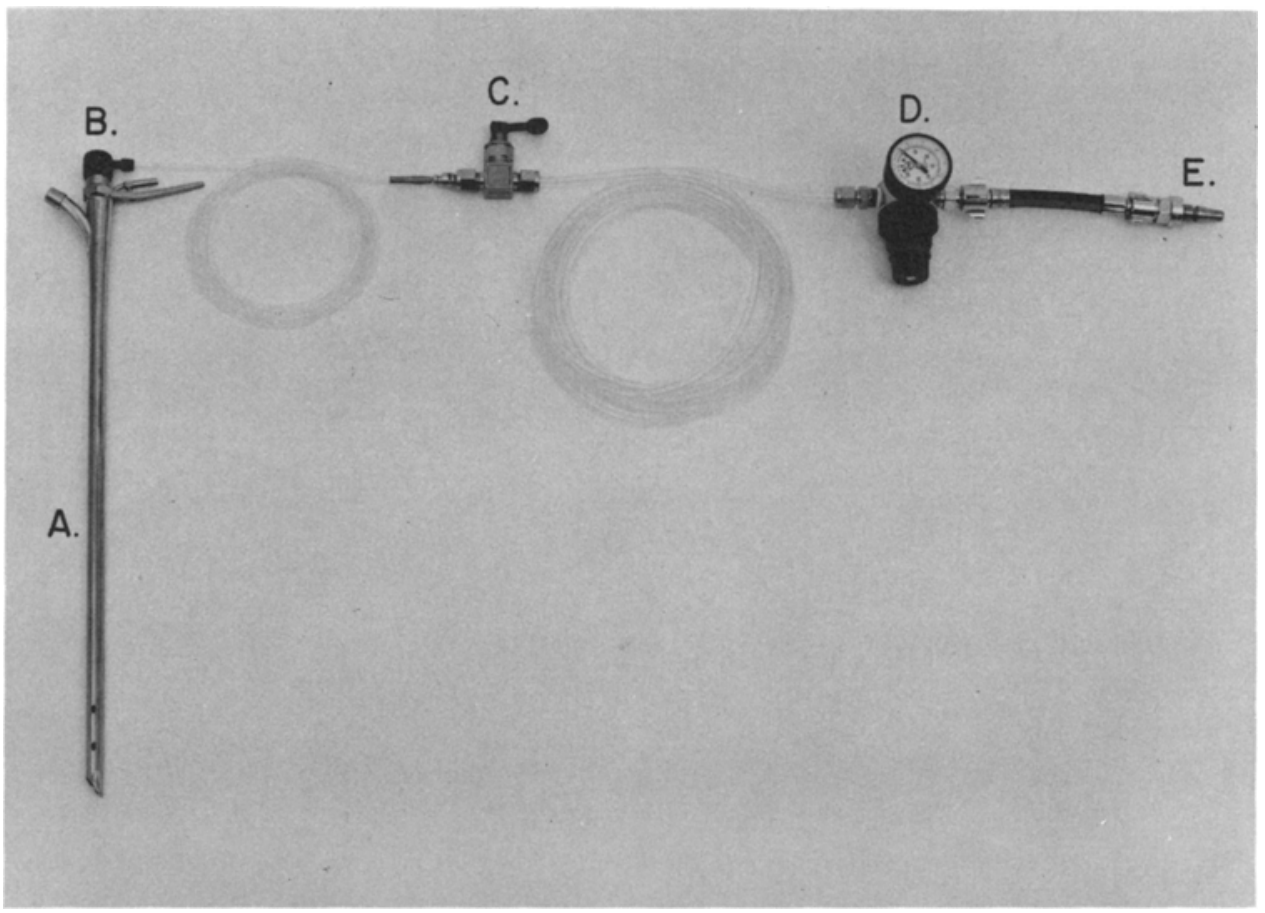

Frgure 3. The Venturi ventilation system showing: A, Bronchoscope (Chevalier JacksonHollinger type ); B, Attachment which has 16-gauge jet affixed; C, Blowgun; D, Pressure reducing valve; $\mathrm{E}$, Schraeder connector.

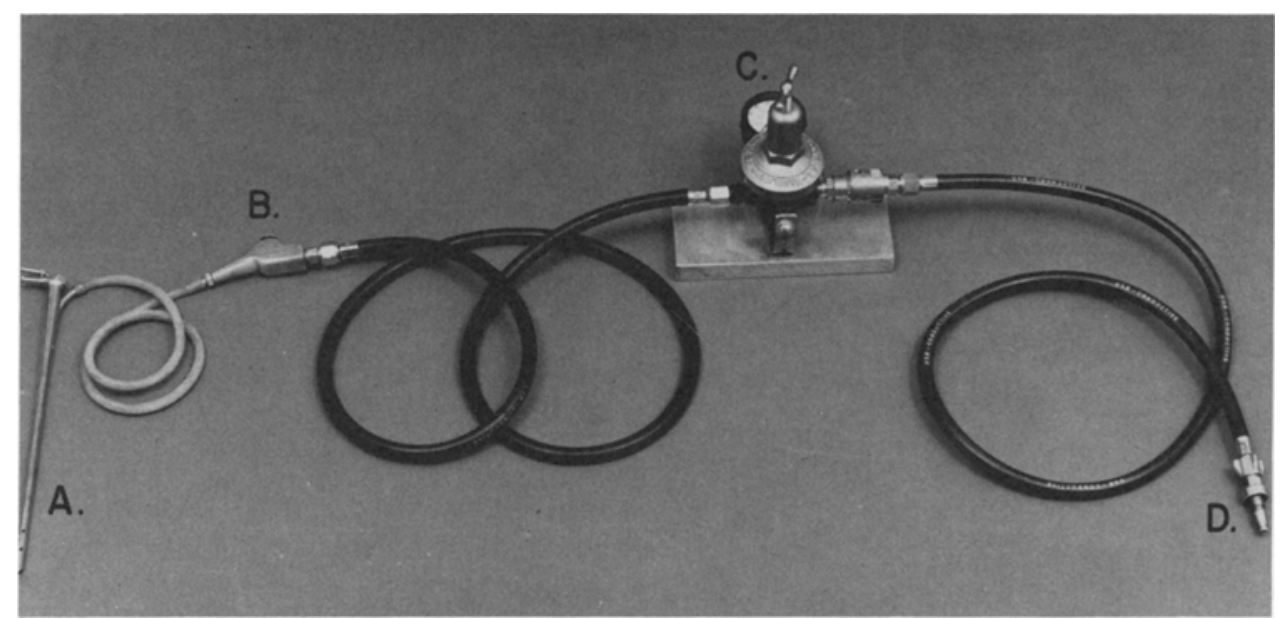

Figure 4. The Sidearm system showing: A, Bronchoscope (Chevalier Jackson); B, Blowgun; C, Pressure reducing valve; D, Schraeder connector. 
TABLE I

Blood Gas Results Obtained From Patients Being Ventilated With the VENTURI SySTEM

\begin{tabular}{|c|c|c|c|c|c|c|c|c|c|}
\hline $\begin{array}{l}\text { Patient } \\
\text { Age }\end{array}$ & $\underset{58}{1}$ & $\begin{array}{l}2 \\
\mathrm{SB} \\
31\end{array}$ & $\begin{array}{l}3 \\
\mathrm{AP} \\
64\end{array}$ & $\begin{array}{c}4 \\
\mathrm{HE} \\
48\end{array}$ & $\begin{array}{c}5 \\
\text { DS } \\
46\end{array}$ & $\begin{array}{c}6 \\
\mathrm{RP} \\
64\end{array}$ & $\begin{array}{c}7 \\
\mathrm{HM} \\
50\end{array}$ & $\begin{array}{c}8 \\
\mathrm{~J} \\
26\end{array}$ & Average \\
\hline $\begin{array}{l}\text { Sex } \\
\text { Bronchoscope } \\
\quad \text { Size }\end{array}$ & $\begin{array}{c}\sigma^{7} \\
8 \times 40\end{array}$ & $\begin{array}{c}0^{7} \\
8 \times 40\end{array}$ & $\begin{array}{c}\sigma^{7} \\
8 \times 40\end{array}$ & $\begin{array}{c}\sigma^{7} \\
8 \times 40\end{array}$ & $\begin{array}{c}\stackrel{9}{7} \\
7 \times 40\end{array}$ & $\begin{array}{c}9 \\
7 \times 40\end{array}$ & $\begin{array}{c}\text { ९ } \\
7 \times 40\end{array}$ & $\begin{array}{c}\sigma^{7} \\
7 \times 40\end{array}$ & \\
\hline
\end{tabular}

Pre Bronchoscopy

\begin{tabular}{|c|c|c|c|c|c|c|c|c|c|}
\hline $\begin{array}{l}\mathrm{aO}_{2} \text { torr } \\
\mathrm{aCO}_{2} \text { torr } \\
\mathrm{H}\end{array}$ & $\begin{array}{l}47 \\
30 \\
7.48\end{array}$ & $\begin{array}{l}68 \\
34 \\
7.43\end{array}$ & $\begin{array}{l}70 \\
36 \\
7.66\end{array}$ & $\begin{array}{l}56 \\
31 \\
7.48\end{array}$ & $\begin{array}{l}94 \\
30 \\
7.51\end{array}$ & $\begin{array}{l}60 \\
32 \\
7.48\end{array}$ & $\begin{array}{l}65 \\
37 \\
7.51\end{array}$ & $\begin{array}{l}87 \\
34 \\
7.50\end{array}$ & $\begin{array}{l}68.4 \\
33\end{array}$ \\
\hline $\begin{array}{l}\mathrm{O}_{2} \text { torr } \\
\mathrm{CO}_{2} \text { torr }\end{array}$ & $\begin{array}{l}\text { hoscopy } \\
108 \\
30 \\
7.45\end{array}$ & $\begin{array}{l}80 \\
31 \\
7.39\end{array}$ & $\begin{array}{l}138 \\
\mathbf{4 3} \\
\mathbf{7} .38\end{array}$ & $\begin{array}{l}62 \\
47 \\
7.21\end{array}$ & $\begin{array}{l}235 \\
25 \\
7.54\end{array}$ & $\begin{array}{l}140 \\
29 \\
7.45\end{array}$ & $\begin{array}{l}115 \\
35 \\
7.49\end{array}$ & $\begin{array}{l}86 \\
40 \\
7.48\end{array}$ & $\begin{array}{c}120.5 \\
35\end{array}$ \\
\hline
\end{tabular}

TABLE II

Blood Gas Results Obtained From Patients Being Ventilated With the SIDEARM SYSTEM

\begin{tabular}{|c|c|c|c|c|c|c|c|c|c|}
\hline $\begin{array}{l}\text { Patient } \\
\text { Age }\end{array}$ & $\begin{array}{c}1 \\
\mathrm{MC} \\
15\end{array}$ & $\begin{array}{l}2 \\
\mathrm{RH} \\
60\end{array}$ & $\begin{array}{l}3 \\
\mathrm{HI} \\
59\end{array}$ & $\begin{array}{c}4 \\
\text { RP } \\
70\end{array}$ & $\begin{array}{c}5 \\
\mathrm{JC} \\
43\end{array}$ & $\begin{array}{c}6 \\
\mathrm{CO} \\
55\end{array}$ & $\begin{array}{c}7 \\
\text { ES } \\
70\end{array}$ & $\begin{array}{c}8 \\
\mathrm{EM} \\
40\end{array}$ & Average \\
\hline $\begin{array}{l}\text { Sex } \\
\text { Bronchoscope } \\
\quad \text { Size }\end{array}$ & $\begin{array}{c}\stackrel{9}{7} \\
7 \times 40\end{array}$ & $\begin{array}{c}0^{7} \\
8 \times 40\end{array}$ & $\begin{array}{c}0^{\pi} \\
8 \times 40\end{array}$ & $\begin{array}{c}0^{\pi} \\
8 \times 40\end{array}$ & $\begin{array}{c}\sigma^{7} \\
8 \times 40\end{array}$ & $\begin{array}{c}0^{7} \\
8 \times 40\end{array}$ & $\begin{array}{c}0^{7} \\
8 \times 40\end{array}$ & $\begin{array}{c}\sigma^{7} \\
8 \times 40\end{array}$ & \\
\hline $\begin{array}{l}\text { Pre Bronchose } \\
\mathrm{PaO}_{2} \text { torr } \\
\mathrm{PaCO}_{2} \text { torr } \\
\text { pH }\end{array}$ & $\begin{array}{l}\text { opy } \\
76 \\
43 \\
7.42\end{array}$ & $\begin{array}{l}78 \\
36 \\
7.44\end{array}$ & $\begin{array}{l}72 \\
39 \\
7.42\end{array}$ & $\begin{array}{l}54 \\
30 \\
7.54\end{array}$ & $\begin{array}{l}46 \\
36 \\
7.44\end{array}$ & $\begin{array}{l}69 \\
36 \\
7.5\end{array}$ & $\begin{array}{l}63 \\
35 \\
7.46\end{array}$ & $\begin{array}{l}78 \\
47 \\
7.42\end{array}$ & $\begin{array}{l}67 \\
37.75\end{array}$ \\
\hline $\begin{array}{l}\text { During Broncl } \\
\mathrm{PaO}_{2} \text { torr } \\
\mathrm{PaCO}_{2} \text { torr } \\
\mathrm{pH}\end{array}$ & $\begin{array}{l}105 c o p y \\
370 \\
35 \\
7.5\end{array}$ & $\begin{array}{l}450 \\
29 \\
7.5\end{array}$ & $\begin{array}{l}305 \\
37 \\
7.44\end{array}$ & $\begin{array}{l}230 \\
40 \\
7.52\end{array}$ & $\begin{array}{l}350 \\
33 \\
7.48\end{array}$ & $\begin{array}{c}385 \\
48 \\
7.44\end{array}$ & $\begin{array}{l}355 \\
37 \\
7.48\end{array}$ & $\begin{array}{l}350 \\
29 \\
7.58\end{array}$ & $\begin{array}{l}349 \\
36.25\end{array}$ \\
\hline
\end{tabular}

expiratory pause (as with a patient undergoing endotracheal anaesthesia who is being artificially ventilated). With the Venturi system ventilation was more shallow at a much more rapid rate and usually the patient was being ventilated at the maximum allowed by this system.

\section{Results}

The blood gas results from the 16 patients are displayed in Tables I and II EKG monitoring did not demonstrate any arrhythmias during the course of bronchosopy. There was no significant difference in blood pressure changes between the two groups.

\section{Discussion}

As seen in Table I and Table II the average $\mathrm{PaO}_{2}$ from the Sidearm technique is much higher than that from the Venturi technique, being 349 torr as compared 
to 120.5 torr. The average $\mathrm{PaCO}_{2}$ is slightly lower with the Venturi technique than with the sidearm technique. This was unexpected, since the sidearm technique delivers far more pressure to the end of the bronchoscope than the Venturi. ${ }^{8}$ The explanation of this interesting result is that more rapid and shallow ventilation was able to compensate for the pressure deficit in the Venturi system. One publication reporting the Venturi technique ${ }^{3}$ showed a slow rise in $\mathrm{CO}_{2}$ levels, during operation and other authors have advocated using oxygen at pressures higher than $50 \mathrm{psi}$ to make up for the lack in ventilation capacity. ${ }^{2}$ We were running the Venturi system with a pressure of 50 psi distal to the reducing valve. Should we have had a patient who developed bronchospasm or one with chronic bronchitis with decreased compliance, for example, there would have been no pressure in reserve to keep alveolar ventilation normal. The Sidearm system, however, was not being used to capacity, since our aim was to keep the $\mathrm{PaCO}_{2}$ between 30 and 40 torr. The patients were ventilated much more slowly and deeply. If the compliance had fallen, there would have been much more ventilation capacity immediately available, and even more by adjusting the pressure reducing valve, to ensure adequate ventilation of the patient.

The sidearm technique delivers much higher oxygen concentrations at higher pressures. Various objections have been leveled against the sidearm technique because these higher pressures might damage the lungs when the bronchoscope is down one bronchus, and also because the use of 100 per cent dry oxygen might cause pulmonary damage. In one institution, over 1000 bronchoscopies $^{9}$ have been carried out with the sidearm technique over the last two years with no record of pulmonary damage resulting from this technique. It may therefore be considered that the technique is safe.

A problem associated with both of these techniques is the use of intravenous barbiturates as the anaesthetic agent. Should the bronchoscopy continue for any length of time, then the post-anaesthetic recovery period will be prolonged. It should be possible to inject nitrous oxide and oxygen mixtures down the bronchoscope, so reducing the dose of barbiturates. The whole procedure could then be carried out with less likelihood of awareness on the part of the patient. This could be done only with the sidearm technique, where there is little or no air entrainment. ${ }^{6,8}$ Further research along these lines is under way. ${ }^{10}$

\section{ConcLusion}

A comparative study has been carried out on the use of the Sidearm system and Venturi system for ventilation during bronchoscopy. It has been demonstrated that the Sidearm system delivered much higher oxygen concentrations and, therefore, gave significantly higher $\mathrm{PaO}_{2}$ levels. It also seemed that by more rapid and shallower ventilation, the lack of pressure developed by the Venturi system when connected to pipeline oxygen at 50 psi can be compensated for and arterial $\mathrm{CO}_{2}$ levels can be kept at physiological levels, provided that patients do not have much decrease in compliance. 


\section{RÉSUMÉ}

Nous avons fait une étude comparative de l'usage d'un système à embouchure de côté et d'un système de Venturi pour faire la ventilation au cours de la bronchoscopie. L'étude a montré que le système à embouchure de oôté permet des taux d'oxygène beaucoup plus élevés et, en conséquence, donne des $\mathrm{PaCO}_{2}$ élevées. Il nous semble également que, avec une ventilation plus rapide et plus superficielle, le manque de pression produit par le système Venturi branché sur la canalisation d'oxygène à $50 \mathrm{lb}$ par $\mathrm{P} 2$ peut compenser pour des taux de $\mathrm{Co}_{2}$ artériels voisins des taux physiologiques, à la condition que les malades ne présentent pas une compliance trop réduite.

\section{ACKNOWLEDGMENTS}

The authors would like to thank Dr. Benson Wilcox, Professor of Cardiovascular and Thoracic Surgery, the University of North Carolina School of Medicine, for his kind assistance in allowing us to carry out these investigations on patients under his care and Mrs. Lane Harrington for her invaluable secretarial help.

\section{REFERENCES}

1. Sanders, R.D. Two ventilating attachments for bronchoscopes. Delaware M.J. $39: 170$ (1967).

2. Spoerel, W.E. Ventilation through an open bronchoscope. Canadian Anaesthetists' Society Journal 16:61 (1969).

3. Morales, G.A., et al. Ventilation during general anesthesia for bronchoscopy. Journal of Thoracic and Cardiovascular Surgery 57: 873 (1969).

4. Fuller, W.R., Davies, D.M., \& Stradling, P. Anaesthesia for bronchoscopy prolonged by teaching and photography. Anaesthesia 27: 292 (1972).

5. Bethune, D.W., Collis, J.M., Burbribce, N.J., \& Forster, D.M. Bronchoscope injectors. A design for use with pipeline oxygen supplies. Anaesthesia 27: 81 (1972).

6. CARden, E., et al. A ventilation system for patients undergoing bronchoscopy. Anesthesiology 33: 454 (1970).

7. Davis, D.A. \& Thornton, W.E. Radiotelemetry in anesthesia and surgery. Int. Anesthesia Clinics 3: 535-545 ( May 1965).

8. Caroen, E. Positive pressure ventilation during anesthesia for bronchoscopy. Anesthesia and Analgesia. In Press.

9. Oulton, J. Personal communication (1972).

10. Carden, E. \& Schwesinger, W. "Further Advances in Bronchoscopic Anesthesia." Anesthesiology. In Press. 